ORIGINAL ARTICLE

\title{
Physiological adaptations to soccer specific endurance training in professional youth soccer players
}

\author{
K McMillan, J Helgerud, R Macdonald, J Hoff
}

Br J Sports Med 2005;39:273-277. doi: 10.1136/bjsm.2004.012526

See end of article for authors' affiliations

Correspondence to

Kenny McMillan, Glasgow

Celtic Football Club,

Medical Department, 95

Kerrydale Street, Glasgow

G40 3RE, UK ;

kennymcmillan@hotmail.

com

Accepted 20 July 2004
Background: Improved oxygen uptake improves soccer performance as regards distance covered, involvements with the ball, and number of sprints. Large improvements in oxygen uptake have been shown using interval running. A similar physiological load arising from interval running could be obtained using the soccer ball in training.

Objectives: The main aim was to study physiological adaptations to a 10 week high intensity aerobic interval training program performed by professional youth soccer players, using a soccer specific ball dribbling track.

Methods: Eleven youth soccer players with a mean (SD) age of $16.9(0.4)$ years performed high intensity aerobic interval training sessions twice per week for 10 weeks in addition to normal soccer training. The specific aerobic training consisted of four sets of $4 \mathrm{~min}$ work periods dribbling a soccer ball around a specially designed track at $90-95 \%$ of maximal heart frequency, with a 3 min recovery jog at $70 \%$ of maximal heart frequency between intervals.

Results: Mean $\mathrm{Vo}_{2 \max }$ improved significantly from $63.4(5.6)$ to $69.8(6.6) \mathrm{ml} \mathrm{kg}^{-1} \mathrm{~min}^{-1}$, or 183.3 (13.2) to 201.5 (16.2) $\mathrm{ml} \mathrm{kg}^{-0.75} \mathrm{~min}^{-1}(\mathrm{p}<0.001)$. Squat jump and counter movement jump height increased significantly from $37.7(6.2)$ to $40.3(6.1) \mathrm{cm}$ and $52.0(4.0)$ to $53.4(4.2) \mathrm{cm}$, respectively $(p<0.05)$. No significant changes in body mass, running economy, rate of force development, or $10 \mathrm{~m}$ sprint times occurred.

Conclusion: Performing high intensity 4 min intervals dribbling a soccer ball around a specially designed track together with regular soccer training is effective for improving the $\mathrm{Vo}_{2 \max }$ of soccer players, with no negative interference effects on strength, jumping ability, and sprinting performance.
D ue to its acyclical nature and intensity, soccer is classified as a high intensity intermittent team sport. ${ }^{1}$ During competitive soccer match play, elite players cover a distance of about $10-12 \mathrm{~km}^{2-5}$ at an average intensity close to the anaerobic threshold, being $80-90 \%$ of maximal heart frequency $\left(\mathrm{Hf}_{\max }\right)$ or $70-80 \%$ of maximal oxygen uptake $\left(\mathrm{Vo}_{2 \max }\right) .^{367}$ It is estimated that aerobic metabolism provides $90 \%$ of the energy cost of soccer match play. Therefore, it is a prerequisite in the modern game for the elite soccer player to have high aerobic endurance fitness. Pate and $\mathrm{Kriska}^{8}$ have described a model that incorporates the three major factors that account for inter-individual variance in aerobic endurance performance, namely $\mathrm{Vo}_{2 \max }$ lactate threshold (LT), and work economy (C), with numerous studies supporting this model. ${ }^{79-13}$ The physiological elements of this model can be used when studying the physiological profiles of soccer players and the physiological adaptations to specific training interventions.

$\mathrm{Vo}_{2 \max }$ is considered to be the most important component of endurance performance. ${ }^{14}{ }^{15}$ Small alterations in LT occur in response to running interventions when LT is expressed as a percentage of $\mathrm{Vo}_{2 \max }{ }^{7}$ Minor changes have been shown for running economy $\left(C_{R}\right)$ after running interventions, although $C_{R}$ is positively influenced by maximal strength training based on maximal mobilisation of force and rate of force development (RFD). ${ }^{16}$

The mean $\mathrm{Vo}_{2 \max }$ of elite soccer players is normally reported to be between 55 and $68 \mathrm{ml} \mathrm{kg}^{-1} \mathrm{~min}^{-1} .^{14}{ }^{17-24}$ These moderate to high values are similar to those found in other team sports, ${ }^{25}$ but are substantially lower than elite endurance performers where values close to $90 \mathrm{ml} \mathrm{kg}^{-1} \mathrm{~min}^{-1}$ have been found..$^{15}$ Individual values higher than $70 \mathrm{ml} \mathrm{kg}^{-1} \mathrm{~min}^{-1}$ for modern soccer players have been recently reported..$^{75} 24$

The importance of $\mathrm{Vo}_{2 \max }$ in soccer has been reflected by rank correlation of the most successful teams in the Hungarian 1st Division Championship. ${ }^{26}$ Wisløff et $a^{24}$ supported this aerobic power-success relationship by demonstrating a clear difference in $\mathrm{Vo}_{2 \max }$ between the top team Rosenborg $\left(67.6 \mathrm{ml} \mathrm{kg}^{-1} \mathrm{~min}^{-1}\right)$ and a lower placed team Strindheim $\left(59.9 \mathrm{ml} \mathrm{kg}^{-1} \mathrm{~min}^{-1}\right)$ in the Norwegian elite division. The observation of a high correlation between $\mathrm{Vo}_{2 \max }$ and distance covered during match play supports the adoption of training regimes that raise the $\mathrm{Vo}_{2 \max }$ of soccer players to high levels. ${ }^{72} 28$ Smaros $^{28}$ reported that in addition to the strong correlation with the total distance covered in the game $(\mathrm{r}=0.89), \mathrm{Vo}_{2 \max }$ also influenced the number of sprints attempted during a match. It has been recently shown that by improving the mean $\mathrm{Vo}_{2 \max }$ of youth soccer players by $11 \%$ over an 8 week period, a $20 \%$ increase in total distance covered during competitive match play was manifested, along with a $23 \%$ increase in involvements with the ball and a $100 \%$ increase in the number of sprints performed by each player. ${ }^{7}$

In activities that involve dynamic work with large muscle mass utilisation, as in playing soccer, it is generally assumed that $\mathrm{Vo}_{2 \text { max }}$ is primarily limited by maximal cardiac output. ${ }^{29}$ Whereas untrained subjects are limited peripherally, trained individuals are primarily limited centrally, with the maximal

Abbreviations: IRM, one repetition maximum; $C$, work economy; $C M J$, counter movement jump; $C_{R}$, running economy; Hf, heart frequency; $\mathrm{Hf}_{\text {max }}$, maximal heart frequency; $\mathrm{LT}$, lactate threshold; RFD, rate of force development; SD, standard deviation; SJ, squat jump; $\mathrm{Vo}_{2 \text { max }}$, maximal oxygen uptake 
stroke volume of the heart being accepted as the major limiting factor of $\mathrm{VO}_{2 \max } \cdot{ }^{30}{ }^{31}$ Increased stroke volume has recently been shown up to the level of $\mathrm{Vo}_{2 \text { max }} \cdot{ }^{32}$

Hoff and Helgerud ${ }^{15}$ thus argue that continuous interval training for 3-8 min with a working intensity of $90-95 \%$ of $\mathrm{Hf}_{\max }$ should increase $\mathrm{Vo}_{2 \max }$ by increasing the maximal cardiac output by improving stroke volume. Recently, Helgerud et $\mathrm{l}^{73}$ showed the effectiveness of such a training regime, significantly increasing mean $\mathrm{Vo}_{2 \max }$ and $\mathrm{C}_{\mathrm{R}}$ of soccer players using running and treadmill running as training modes, respectively. Similar physiological load could be obtained by using a specifically designed soccer track where the subjects dribble a soccer ball instead of regular running. ${ }^{34}$ This might however raise different problems in terms of the subjects and coaches' control of intensity, control of the ball, etc, that might influence training execution and response.

The main aim of this study was to intervene in a professional youth soccer team using high intensity interval training with the players dribbling a soccer ball around a specifically designed track. An improvement in $\mathrm{Vo}_{2 \max }$ of similar magnitude as that attained by Helgerud et al for youth players and by Helgerud et $a l^{33}$ for Champions League players was hypothesised, with no adverse effects on sprinting and jumping ability. A secondary aim of this study was to present normative physiological data on professional youth soccer players.

\section{METHODS \\ Subjects}

Sixteen male youth soccer players from Celtic Football Club's U-17's Youth Academy squad (Glasgow, Scotland, UK) participated in the study. The players studied were all full time professional soccer players and trained on a daily basis. Seven of the players tested are of international standard for their age group. Each subject reviewed and signed consent forms in accordance with the Declaration of Helsinki and the Human Research Review Committee at the Norwegian University of Science and Technology prior to the study. Subjects were informed about the test protocols, but without being informed about the aim of the study. The players' physical characteristics are presented in table 1.

\section{Testing}

Each player's mass and height were recorded upon entering the laboratory. The players then performed a 10 min warm up on a treadmill (Technogym RunRace, Gambettola, Italy) at an intensity of approximately $60-70 \%$ of $\mathrm{Vo}_{2 \max }$. Squat jump (SJ) height with no arm swing, counter movement jump (CMJ) height with no arm swing, and RFD were determined using a force platform (Kistler, Winterthur, Switzerland). Jumping height was determined as the centre of mass displacement calculated from force-time characteristics and body mass. The best jump from three attempts was recorded. A 2 min rest period was allowed between efforts. Hands were placed on the hips during the jump tests. RFD was calculated from an SJ performed from a position with a $90^{\circ}$ angle in the knee joint (between femur and tibia). RFD was calculated as the force from 10 to $90 \%$ of peak external force registered from the force platform divided by the time used to exert that force. The same start and peak force

\begin{tabular}{llll} 
Table 1 & Physical characteristics of players $(\mathrm{n}=11)$ \\
\hline Age (years) & Height $(\mathrm{cm})$ & Mass $(\mathrm{kg})$ & $\mathrm{Hf}_{\max }$ (beats min $\left.{ }^{-1}\right)$ \\
\hline $16.9(0.4)$ & $177.0(6.4)$ & $70.6(8.1)$ & $199(8)$ \\
\hline
\end{tabular}

Values are mean (SD). window from the pre-test was used to obtain changes in RFD at the post-test. ${ }^{35}$ One repetition maximum (IRM) strength was then obtained as the maximal weight the subjects were able to raise in a half squat $\left(90^{\circ}\right.$ angle in the knee joint between femur and tibia). Testing was carried out using $5 \mathrm{~kg}$ stages and 1-2 min between each trial. IRM was normally determined using three to five trials.

Then 5 min after completion of the strength testing, each player commenced treadmill testing of $\mathrm{C}_{\mathrm{R}}$ and $\mathrm{Vo}_{2 \max }$. $\mathrm{C}_{\mathrm{R}}$ was measured at $9 \mathrm{~km} \mathrm{~h}^{-1}$ at a treadmill inclination of $5.5 \%$. The average value of oxygen uptake $\left(\mathrm{Vo}_{2 \max }\right)$ between 4 and $4.5 \mathrm{~min}$ was used to calculate $\mathrm{C}_{\mathrm{R}}$. The velocity of the treadmill was then increased by $1 \mathrm{~km} \mathrm{~h}^{-1}$ every minute to a level that brought the subject close to exhaustion after approximately 5-6 min. Inclination of the treadmill was kept constant at $5.5 \%$. Heart frequency ( $\mathrm{Hf}$ ) was determined using short range radio telemetry (Polar Accurex Plus, Polar Electro, Kempele, Finland). The highest Hf measured throughout the test was recorded as $\mathrm{Hf}_{\text {max }}$. $\mathrm{Vo}_{2 \text { max }}$, minute ventilation, and breathing frequency were measured using a Cortex Metamax II device (Cortex, Leipzig, Germany), a portable metabolic test system that has been previously validated..$^{36}$

On the following day, each player's sprint acceleration was assessed over a $10 \mathrm{~m}$ distance. ${ }^{37}$ After a $15 \mathrm{~min}$ warm up, each player carried out three maximal sprints from a static position ( $0 \mathrm{~m}$ behind first photocell), with each trial separated by $3 \mathrm{~min}$ of rest. The sprint tests were performed on an indoor running track and $10 \mathrm{~m}$ sprint time was recorded using photocells (Newtest Powertimer, Oulu, Finland).

\section{Training intervention}

The aerobic training intervention consisted of interval training, comprising four bouts of 4 min work periods dribbling a soccer ball (Mitre ISO League, Mitre, Wilmslow, Cheshire, UK) around a specially designed $\operatorname{track}^{34}$ (fig 1) on an artificial field-turf pitch. Training cones used in the dribbling circuit were $0.3 \mathrm{~m}$ high and $0.15 \mathrm{~m}$ wide. Hurdle height was set at $0.5 \mathrm{~m}$. Working intensity was at $90-95 \%$ of each player's $\mathrm{Hf}_{\text {max }}$, with work periods separated by 3 min of jogging at $70 \%$ of $\mathrm{Hf}_{\max }$. All players wore a Polar Team System heart rate belt and monitor (Polar Electro) throughout the interval training. The interval training was performed two times a week at the end of the soccer training session, on the same days and time of day throughout the intervention period. No emphasis was placed on improving strength, sprinting, or jumping performance throughout the intervention period. The 10 week intervention period was carried out directly after the off-season intermission period, encompassing the 6 week pre-season preparation period and the first 4 weeks of the competitive season.

\section{Allometric scaling}

Oxygen uptake is a measure of power and, in order to be independent of absolute body mass, should be expressed in $\mathrm{ml}$ per $\mathrm{kg}$ lean body mass raised to a power of $0.67 .{ }^{38} \mathrm{Vo}_{2 \max }$ expressed as $\mathrm{ml} \mathrm{kg}^{-1} \mathrm{~min}^{-1}$ implies 1 : 1 linearity between oxygen uptake and body mass, which is not the case. ${ }^{39}$ When expressing $\mathrm{Vo}_{2 \max }$ as $\mathrm{ml} \mathrm{kg}^{-1} \mathrm{~min}^{-1}$, light individuals are over-estimated in terms of work capacity and heavy individuals are under-estimated. The opposite is true when evaluating the oxygen cost of running at sub-maximal workloads. When comparisons amongst people of different body mass are made for running, oxygen uptake should be expressed as $\mathrm{ml} \mathrm{kg} \mathrm{kg}^{-0.75} \mathrm{~min}^{-1} .^{13} 39$ Expressing $\mathrm{Vo}_{2 \max }$ in relation to the power 0.67 or 0.75 may not be critical as long as the unit approximates the theoretical value and not the traditional body mass. ${ }^{13}$ 


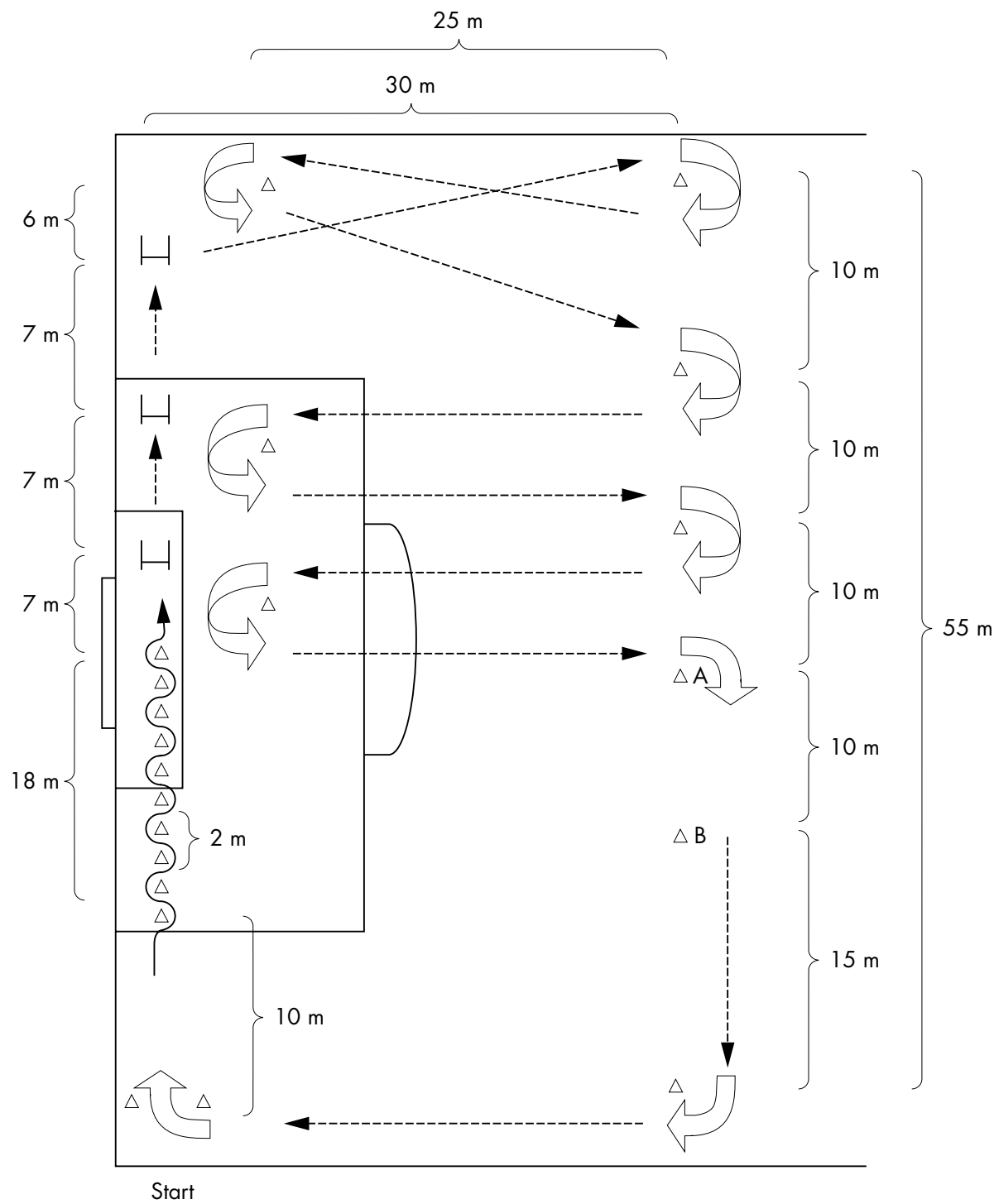

Figure 1 Soccer specific dribbling track used for high intensity interval training sessions. Players dribble a soccer ball around the track, liff the soccer ball over the hurdles, and jump over the hurdles. Players dribble backwards with the soccer ball between points $A$ and $B$.

\section{Statistical analysis}

All results are reported as means and standard deviations (SD) calculated by conventional procedures. Differences from pre- to post-training were calculated using a $t$ test, with results accepted as significant at $\mathrm{p}<0.05$. Changes from preto post-training in $\mathrm{Vo}_{2 \max }$ and $\mathrm{C}_{\mathrm{R}}$ given in per cent are calculated on the basis of the unit $\mathrm{ml} \mathrm{kg}^{-0.75} \mathrm{~min}^{-1}$.

\section{RESULTS}

During the 10 week, twice a week intervention, the players in this study completed $16(80 \%)$ of the scheduled 20 interval training sessions. Four sessions were uncompleted due to the players competing in a 1 week tournament and mid-week competitive matches. Five players of the 16 assessed preintervention were withdrawn from the study due to injuries not connected with the training intervention (three players) and unavailability at the post-intervention session (two players).

The 10 week aerobic training intervention manifested significant improvements in $\mathrm{Vo}_{2 \max }$ (table 2) of $9 \%$ $(\mathrm{p}<0.001)$. The mean $\mathrm{Vo}_{2 \max }$ increased from 4.45 (0.37) to $4.87(0.45) 1 \mathrm{~min}^{-1}$, which equates to a change from 63.4
(5.6) to $69.8(6.6) \mathrm{ml} \mathrm{kg}^{-1} \mathrm{~min}^{-1}$, or 183.3 (13.2) to 201.5 (16.2) $\mathrm{ml} \mathrm{kg}^{-0.75} \mathrm{~min}^{-1}$. Mean body mass was unchanged after the intervention period.

When treadmill running at $9 \mathrm{~km} \mathrm{~h}^{-1}$ at an inclination of $5.5 \%, C_{R}$ was unchanged by the intervention. However, mean $\mathrm{Hf}$ at this workload decreased significantly from 162 (14) to 154 (14) beats $\min ^{-1}(\mathrm{p}<0.05)$.

No significant changes in RFD and $10 \mathrm{~m}$ sprint performance were evident. SJ and CMJ height increased from 37.7 (6.2) to $40.3(6.1) \mathrm{cm}$ and 52.0 (4) to $53.4(4.2) \mathrm{cm}$, respectively $(\mathrm{p}<0.05)$.

\section{DISCUSSION}

The training intervention used in this study elevated mean $\mathrm{Vo}_{2 \max }$ by $6.4 \mathrm{ml} \mathrm{kg}^{-1} \min ^{-1}$ or $9.0 \%$. Mean $\mathrm{Vo}_{2 \max }$ increased from a typical soccer player value of 63.4 (5.6) to $69.8(6.6) \mathrm{ml} \mathrm{kg}^{-1} \mathrm{~min}^{-1}$, or 183.3 (13.2) to 201.5 (16.2) $\mathrm{ml} \mathrm{kg}^{-0.75} \mathrm{~min}^{-1}$. Removing the goalkeeper's $V_{o_{2} \max }$ value from the pre- and post-intervention results shows an improvement in mean $\mathrm{Vo}_{2 \max }$ from 64.7 (3.9) to 70.9 (5.7) $\mathrm{ml} \mathrm{kg}^{-1} \mathrm{~min}^{-1}$, or 186.3 (9.2) to 204.0 (14.8) $\mathrm{ml} \mathrm{kg}^{-0.75} \mathrm{~min}^{-1}$ for the outfield players $(\mathrm{n}=10)$. 
Table 2 Pre- and post-training intervention physiological results $(n=11)$

\begin{tabular}{|c|c|c|}
\hline & Pre-training & Post-training \\
\hline Body mass (kg) & $70.6(8.1)$ & $70.2(8.2)$ \\
\hline \multicolumn{3}{|l|}{$\mathrm{Vo}_{2 \max }$} \\
\hline $1 \min ^{-1}$ & $4.45(0.37)$ & $4.87(0.45)^{\star *}$ \\
\hline $\mathrm{ml} \mathrm{kg}{ }^{-1} \min ^{-1}$ & $63.4(5.6)$ & $69.8(6.6)^{* *}$ \\
\hline $\mathrm{ml} \mathrm{kg}-0.75 \min ^{-1}$ & $183.3(13.2)$ & $201.5(16.2)^{*}$ \\
\hline \multicolumn{3}{|c|}{$C_{R}\left(9 \mathrm{~km} \mathrm{~h}^{-1}, 5.5 \%\right.$ inclination) } \\
\hline $\mathrm{ml} \mathrm{kg}-0.75 \mathrm{~m}^{-1}$ & $0.85(0.06)$ & $0.85(0.05)$ \\
\hline Hf (beats $\min ^{-1}$ ) & $162(14)$ & $154(14)^{*}$ \\
\hline \multicolumn{3}{|l|}{ Strength } \\
\hline IRM half squat $(\mathrm{kg})$ & - & $129.1(11.4)$ \\
\hline $\begin{array}{l}\text { Relative strength } \\
\left(\mathrm{kg} \mathrm{kg}(\mathrm{bm})^{-1}\right)\end{array}$ & - & $1.85(0.12)$ \\
\hline $\begin{array}{l}\text { Relative strength } \\
\left(\mathrm{kg} \mathrm{kg}(\mathrm{bm})^{-0.67)}\right.\end{array}$ & - & $7.49(0.39)$ \\
\hline \multicolumn{3}{|l|}{ Sprint test } \\
\hline $10 \mathrm{~m}(\mathrm{~s})$ & $1.96(0.07)$ & $1.96(0.06)$ \\
\hline \multicolumn{3}{|l|}{ Force platform tests } \\
\hline $\operatorname{RFD}\left(\mathrm{N} \mathrm{s}^{-1}\right)$ & 3553 (1492) & $3654(1487)$ \\
\hline SJ $(\mathrm{cm})$ & $37.7(6.2)$ & $40.3(6.1)^{*}$ \\
\hline$C M J(\mathrm{~cm})$ & $52.0(4)$ & $53.4(4.2)^{*}$ \\
\hline
\end{tabular}

Helgerud et $\mathrm{al}^{7}$ used 4 min intervals at $90-95 \% \mathrm{Hf}_{\max }$ with youth soccer players over an 8 week training period and promoted a $\mathrm{Vo}_{2 \max }$ increase of $11 \%$, an increase from 58.1 (4.5) to 64.3 (3.9) $\mathrm{ml} \mathrm{kg}^{-1} \mathrm{~min}^{-1}$. Although the players in the present study had a mean $\mathrm{Vo}_{2 \max }$ score greater than the post-intervention values found by Helgerud et al, large improvements in $\mathrm{Vo}_{2 \max }$ were still attained. The training intervention of Helgerud et $a l^{7}$ manifested improvements in $\mathrm{Vo}_{2 \max }$ of $0.67 \%$ per training session, compared to $0.56 \%$ in the present study. The somewhat greater efficiency of Helgerud's intervention may be due to the lower initial aerobic fitness levels of the Norwegian junior players in that experiment.

The initial and post-intervention mean $\mathrm{Vo}_{2 \max }$ values of the Scottish youth players assessed in the present study are greater than those of Norwegian youth players of similar age $^{7}$ and also of Spanish Premier Liga soccer players. ${ }^{40}$ Indeed, the $\mathrm{Vo}_{2 \max }$ of the Scottish players in this study are comparable to elite Norwegian Champions League soccer players, who possessed a mean (SD) $\mathrm{Vo}_{2 \max }$ of 200.2 (8.4) $\mathrm{ml} \mathrm{kg}^{-0.75} \mathrm{~min}^{-1}$, which are the highest oxygen uptake values reported for a soccer team. ${ }^{24}$ It is suggested that the modern $75 \mathrm{~kg}$ soccer player should have a $\mathrm{Vo}_{2 \max }$ above $70 \mathrm{ml} \mathrm{kg}^{-1} \mathrm{~min}^{-1}$, or $205 \mathrm{ml} \mathrm{kg}{ }^{-0.75} \mathrm{~min}^{-1} .{ }^{15}$ Five players in this study attained a $V_{2 \max }$ greater than $205 \mathrm{ml} \mathrm{kg}^{-0.75} \mathrm{~min}^{-1}$ after the intervention period, with none of the players possessing this level of aerobic fitness pre-intervention.

The first 6 weeks of the intervention period in this study encompassed the pre-season training regime, and it is plausible that some of the improvements in $\mathrm{Vo}_{2 \max }$ manifested were attributable to the players returning to preseason in a de-trained state, due to the 6 week summer intermission period. It is also plausible that improvements in $\mathrm{Vo}_{2 \text { max }}$ in this study may have resulted from the conventional soccer training the players participated in (for example, small-sided game play, technical/tactical training), although it should be noted that the only endurance training that the players performed over the pre-season period in this training study were the high intensity aerobic interval sessions. Some studies have not reported large changes in $\mathrm{Vo}_{2 \max }$ of soccer players after pre-season training. For example, Bangsbo ${ }^{1}$ reported only small increases in $\mathrm{Vo}_{2 \max }$ after a 5 week preseason training period in professional soccer players.
The authors of this study are aware that this study would have benefited from data from a control group. The use of controls is difficult, if not impossible, when dealing with professional soccer clubs and players. However, control group data from a previous study by Helgerud et $\mathrm{al}^{7}$ can be referred to. The control group performed additional technical training whilst the training group performed high intensity aerobic interval training $\left(4 \times 4 \mathrm{~min}\right.$ intervals at $\left.90-95 \% \mathrm{Hf}_{\max }\right)$ twice a week for 8 weeks. The $\mathrm{Vo}_{2 \max }$ of the training group improved by $11 \%$ over the 8 week intervention, but the $\mathrm{Vo}_{2 \max }$ of the control group was unchanged (58.4 (4.3) to 59.5 (4.4) $\mathrm{ml} \mathrm{kg}^{-1} \mathrm{~min}^{-1}$ ).

The $C_{R}$ of the players in this study was not significantly changed after the training intervention. This is in contrast to the findings of Helgerud et al who reported an improved $C_{R}$ of $6.7 \%$ in junior players, but of only $3.7 \%$ when using treadmill training with elite players, ${ }^{33}$ with the latter improvement explained by gains arising from concurrent maximal strength training. It should be noted that the training intervention of Helgerud et al involved straight line running only, therefore an improved $C_{R}$ may be expected for junior players with relatively low endurance values on the basis of more running practice. The aerobic endurance intervention in the present study was carried out dribbling a soccer ball around a specially designed track. ${ }^{34}$ Dribbling a soccer ball around the track raises the oxygen demand when compared to running, ${ }^{41}$ as does the frequent changes in direction and pace involved. Hoff $e t a^{34}$ reported that a mean exercise intensity of $93.5 \% \mathrm{Hf}_{\max }$ when dribbling a soccer ball around the track corresponded to $91.7 \% \mathrm{Vo}_{2 \max }$. $\mathrm{C}_{\mathrm{R}}$ was unchanged in the present study, but it can be postulated that soccer specific work economy may have improved somewhat, with relevant gains not detectable by conventional treadmill testing.

Although $C_{R}$ was unchanged after the intervention period, mean $\mathrm{Hf}$ for treadmill running at $9 \mathrm{~km} \mathrm{~h}^{-1}$ at $5.5 \%$ inclination decreased significantly from 162 (14) to 154 (14) beats $\min ^{-1}(\mathrm{p}<0.001)$. This decrease in Hf could be attributed to an increased $\mathrm{Vo}_{2 \max }$. A reduction in submaximal Hf of approximately 10 beats $\mathrm{min}^{-1}$ is indicative of an increase in $\mathrm{Vo}_{2 \max }$ of approximately 3-5 $\mathrm{ml} \mathrm{kg}^{-1} \min ^{-1}$. $^{13} 33$

Several authors have concluded that endurance training inhibits or interferes with strength ${ }^{42-45}$ and therefore power performance. ${ }^{46}$ IRM half squat strength was measured preand post-intervention in the present study, but due to the players being limited by technique and apprehension as they were not familiar with this exercise movement, the recorded values for the pre-intervention assessment results were artificially low. During the final 4 weeks of the endurance training intervention period technical training for carrying out a safe half squat was performed twice a week using an unloaded Olympic bar. Therefore, only post-intervention squat strength scores for the players in this study are reported. RFD and $10 \mathrm{~m}$ sprint times in the present study were unaffected by the aerobic intervention program and the lifting technique program, although jumping height improved significantly over the 10 week period $(p<0.05)$. Therefore, it appears that power related performance was not hindered by the aerobic interval training regime used in the present study. Similarly, Helgerud et al showed substantial gains in $\mathrm{Vo}_{2 \max }$ from an 8 week endurance training intervention with no reduction in sprinting and jumping abilities.

High intensity aerobic 4 min intervals are an effective tool for increasing $\mathrm{Vo}_{2 \max }$ in soccer players, with the training effect of each session being approximately $0.5 \%$. The results from this study and that of Helgerud et $a l^{73}$ demonstrate that it is possible to elevate the $\mathrm{Vo}_{2 \max }$ of youth soccer players from typical values (for example, $58-64 \mathrm{ml} \mathrm{kg}^{-1} \mathrm{~min}^{-1}$ ) to 


\section{What is already known on this topic}

Improving $\mathrm{Vo}_{2 \max }$ in soccer players has previously been shown to significantly increase work rate during competitive soccer match play. It has previously been demonstrated that the $\mathrm{Vo}_{2 \max }$ of soccer players can be increased by performing high intensity aerobic interval training at $90-95 \%$ of $\mathrm{Hf}_{\max }$ using conventional running.

levels approaching or exceeding $70 \mathrm{ml} \mathrm{kg}^{-1} \mathrm{~min}^{-1}$ without hindering power related performance. For example, soccer players with a moderate initial $\mathrm{Vo}_{2 \max }$ of approximately $60 \mathrm{ml} \mathrm{kg}{ }^{-1} \min ^{-1}$ can raise their $\mathrm{Vo}_{2 \max }$ to a level approaching $70 \mathrm{ml} \mathrm{kg}^{-1} \mathrm{~min}^{-1}$ by performing four sets of $4 \mathrm{~min}$ high intensity intervals at $90-95 \% \mathrm{Hf}_{\max }$ twice a week over a 10 week training period, in addition to regular soccer training.

In conclusion, high intensity aerobic interval training can be effectively performed by dribbling a soccer ball around a specially designed track. The addition of high intensity interval training at $90-95 \% \mathrm{Hf}_{\max }$ to the training regimes of professional youth soccer players can elevate $\mathrm{Vo}_{2 \max }$ levels from low to moderate values to that of elite Champions League soccer players, with no negative interference effects on strength, jumping ability, and sprint performance.

\section{Authors' affiliations}

K McMillan, R Macdonald, Glasgow Celtic Football Club, Glasgow, UK J Helgerud, J Hoff, Department of Circulation and Medical Imaging, Faculty of Medicine, Norwegian University of Science and Technology, Trondheim, Norway

Competing interests: none declared

\section{REFERENCES}

1 Bangsbo J. The physiology of soccer - with special reference to intense intermittent exercise. Acta Physiol Scand 1994;151:S619.

2 Withers RT. Match analyses of Australian professional soccer players. $J$ Hum Mov Stud 1982;8:159-76.

3 Van Gool D, Van Gerven D, Boutmans J. The physiological load imposed on soccer players during real match-play. In: Reilly T, Lees A, Davids K, et al, eds. Science and football. London: E \& FN Spon, 1988:51-9.

4 Ohashi J, Togari H, Isokawa M, et al. Measuring movement speeds and distances covered during soccer match-play. In: Reilly T, Lees A, Davids K, et al, eds. Science and football. London: E \& FN Spon, 1988:329-33.

5 Bangsbo J, Nørregaard, L, Thorsøe F. Activity profile of competition soccer. Can J Sport Sci 1991;16:110-6.

6 Reilly T. Physiological profile of the player. In: Ekblom B, ed. Football (soccer). London: Blackwell, 1994:78-95.

7 Helgerud J, Engen LC, Wisloff U, et al. Aerobic endurance training improves soccer performance. Med Sci Sports Exerc 2001;11:1925-31.

8 Pate RR, Kriska A. Physiological basis of the sex difference in cardiorespiratory endurance. Sports Med 1984;1:87-98.

9 Pollock ML. Submaximal and maximal working capacity of elite distance runners. Part 1: Cardiorespiratory aspects. Ann N Y Acad Sci 1977;301:310-22.

10 Farrell PA, Wilmore $\mathrm{JH}$, Coyle EF, et al. Plasma lactate accumulation and distance running performance. Med Sci Sports Exerc 1979;11:338-44.

11 Conley DL, Krahenbuhl GS. Running economy and distance running performance of highly trained athletes. Med Sci Sports Exerc 1980;12:248-52

12 Di Prampero PE, Atcho G, Brückner JC, et al. The energetics of endurance running. Eur J Appl Physiol 1986;55:259-66.

13 Helgerud J. Maximal oxygen uptake, anaerobic threshold and running economy in women and men with similar performance levels in marathons. Eur J Appl Physiol 1994;68:155-61.

14 Åstrand PØ, Rodahl K. Textbook of work physiology. New York: McGrawHill, 1986.

15 Hoff J, Helgerud J. Endurance and strength training for soccer players. Physiological considerations. Sports Med 2004;34:165-80.

16 Hoff J, Helgerud J, Wisløff U. Endurance training into the next millennium; muscular strength training effects on aerobic endurance performance: a review. Am J Med Sports 2000;4:58-67.
What this study adds

This study has shown that high intensity aerobic interval training designed to increase $\mathrm{Vo}_{2 \max }$ can be performed effectively by dribbling a soccer ball around a specially designed track. Performing high intensity aerobic interval training in addition to conventional soccer training can elevate the $\mathrm{Vo}_{2 \max }$ of soccer players to levels approaching $70 \mathrm{ml} \mathrm{kg}^{-1} \min ^{-1}$

17 Williams C, Reid RM, Couttes R. Observation on the aerobic power of university rugby players and professional soccer players. $\mathrm{Br} J$ Sports Med 1973;7:390-1.

18 Withers RT, Roberts RGD, Davies GJ. The maximum aerobic power anaerobic power and body composition of South Australian male representatives in athletics, basketball, field hockey and soccer. J Sports Med Phys Fitness 1977;17:391-400.

19 Thomas V, Reilly T. Fitness assessment of English League soccer players throughout the competitive season. Br J Sports Med 1979;13:103-9.

20 Rhodes EC, Mosher RE, McKenzie DC, et al. Physiological profiles of the Canadian Olympic soccer team. Can J Appl Sport Sci 1986;1 1:31-6.

21 Nowacki PE, Cai DY, Buhl C, et al. Biological performance of German soccer players (professionals and juniors) tested by special ergometry and treadmill methods. In: Reilly T, Lees A, Davis K, et al, eds. Science and football. London: E \& FN Spon, 1988:145-57.

22 White JE, Emery TM, Kane JL, et al. Pre-season fitness profiles of professional soccer players. In: Reilly T, Lees A, Davis K, et al, eds. Science and football. London: E \& FN Spon, 1988:164-71

23 Davis J, Brewer J, Atkin D. Pre-season physiological characteristics of English first and second division soccer players. J Sports Sci 1992;10:541-7.

24 Wisløff U, Helgerud J, Hoff J. Strength and endurance of elite soccer players. Med Sci Sports Exerc 1998;30:462-7.

25 Ekblom B. Applied physiology of soccer. Sports Med 1986;3:50-60.

26 Apor P. Successful formulae for fitness training. In: Reilly T, Lees A, Davis K, et al, eds. Science and football. London: E \& FN Spon, 1988:95-107.

27 Reilly T, Thomas $\mathrm{V}$. A motion analysis of work-rate in different positional roles in professional football match-play. J Hum Mov Stud 1976;2:87-97.

28 Smaros G. Energy usage during a football match. In: Vecciet L, ed. Proceedings of the 1st International Congress on Sports Medicine Applied to Football. Rome: D Guanillo, 1980:795-801.

29 Wagner PD. Determinants of maximal oxygen transport and utilisation. Annu Rev Physiol 1996;58:21-50

30 Wagner PD. New ideas on limitations to $\mathrm{VO}_{2 \max }$. Exerc Sport Sci Rev 2000;1:10-14.

31 Richardson RS. What governs skeletal muscle VO2max? New evidence. Med Sci Sports Exerc 2000;32:100-7.

32 Zhou B, Conlee RK, Jensen R, et al. Stroke volume does not plateau during graded exercise in elite male distance runners. Med Sci Sports Exerc 2001;33:1849-54.

33 Helgerud J, Kemi OJ, Hoff J. Pre-season concurrent strength and endurance development in elite soccer players. In: Hoff J, Helgerud J, eds. Football (soccer): new developments in physical training research. Trondheim: NTNU, 2003:53-65.

34 Hoff J, Wisløff U, Engen LC, et al. Soccer specific aerobic endurance training. Br J Sports Med 2002;36:218-21.

35 Almåsbakk B, Hoff J. Coordination, the determinant of velocity specificity? J Appl Physiol 1996;80:2046-52.

36 Torvik PØ, Helgerud J. The validity of the portable metabolic test system Cortex Metamax. In: Müller E, ed. Science and skiing II. Hamburg: Verlag Dr Kovac, 2001:641-54

37 Cometti G, Maffiuletti NA, Pousson M, et al. Isokinetic strength and anaerobic power of elite, subelite, and amateur French soccer players. Int J Sports Med $2001 ; 22: 45-51$

38 von Döbeln W. Maximal oxygen uptake, body size and total haemoglobin in normal man. Acta Physiol Scand 1956;95:153-65.

39 Bergh U, Sjødin B, Forsberg A, et al. The relationship between body mass and oxygen uptake during running in humans. Med Sci Sports Exerc 1991:23:205-11.

40 Casajus JA. Seasonal variation in fitness variables in professional soccer players. J Sports Med Phys Fitness 2001;41:463-9.

41 Reilly T, Ball D. The net physiological cost of dribbling a soccer ball. Res Q Exerc Sport 1984:55:267-71

42 Dudley GA, Diamil R. Incompatibility of endurance - and strength - training modes of exercise. J Appl Physiol 1985;59:1446-51.

43 Chromiac JA, Mulvaney DR. A review: the effects of combined strength and endurance training on strength development. J Appl Sport Sci Res 1990;4:55-60.

44 Nelson AG, Arnall DA, Loy SF, et al. Consequences of combining strength and endurance regimens. Phys Ther 1990;70:287-94.

45 Hennessy LC, Watson AWS. The interference effects of training for strength and endurance simultaneously. J Strength Cond Res 1994;8:9-12.

46 Schmidtbleicher D. Training for power event. In: Komi P, ed. Strength and power in sport. London: Blackwell, 1992:381-95. 